\title{
MULTIPLE MARROW CULTURES FROM A SINGLE ASPIRATE
}

\author{
BY \\ R. B. THOMPSON \\ From the Royal Victoria Infirmary, Newcastle-upon-Tyne
}

(RECEIVED FOR PUBLICATION DECEMBER 3, 1949)

Osgood and Brownlee (1937) described a simple method of bone marrow culture. They employed $20 \mathrm{ml}$. serum bottles containing a plasma or serum medium diluted with a physiological salt solution. Since the volume of marrow aspirate is limited to 1-2 ml., and it is best to have 1-2,000 cells per ml. of medium, one experiment is usually limited to five or six cultures. This method permits of as many as 30 cultures being explanted from one specimen of marrow.

\section{Method}

The media are prepared in serum bottles as in Osgood's method, but the cultures are carried out in $100 \times 3 \mathrm{~mm}$. tubes sealed at one end. This capillary bore prevents escape of the medium on inversion of the tubes. Using Pasteur pipettes the tubes are filled with medium, allowing 2.0 to $2.5 \mathrm{~cm}$. for the marrow. The filled tubes are inverted in open sterile serum bottles and placed in readiness in an incubator at $37.5^{\circ} \mathrm{C}$. If several tubes are filled with the same medium specimens may be examined at intervals.

Using a Salah needle, 1.5 to $2.0 \mathrm{ml}$. marrow is aspirated (larger samples tend to be unduly diluted with blood). The specimen is injected into a serum bottle containing Geys' solution at $37.5^{\circ} \mathrm{C}$. and cellular masses are broken up by forcefully sucking the suspension to and fro from container to syringe. The marrow cells are then washed free of plasma by centrifuging and resuspending in fresh uncitrated Geys' solution. (The volume of Geys' solution used depends on the cellularity of the specimen and the number of tubes to be used in the culture.) Nucleated cell counts may be made at any stage. The final marrow suspension is then injected into the culture tubes, using a fine-bore syringe of the type used in tuberculin testing. The marrow cells are readily distributed throughout the tubes by inversion; a horizontal position during culture ensures an even distribution of cells.

After culture the tubes are centrifuged at 1,500 revolutions for 15 minutes, the medium is withdrawn, and smears are made from the cellular deposit.

In each of 10 such experiments satisfactory smears were obtained. Scrupulous care is required at every stage to prevent infection. The technique has been used for studying the conditions influencing the maturation of megaloblastic marrows. 


\section{Summary}

A method is described whereby numerous cultures can be carried out on single specimens of aspirated bone marrow.

The author is indebted to Dr. Laslo Lajtha for instruction in the Osgood technique, and to Dr. C. C. Ungley for much help and for facilities in carrying out the cultures.

\section{REFERENCES}

Osgood, E. E., and Brownlee, I. E. (1937). J. Amer. med. Ass., 108, 1793. 